\title{
Application of Tank Model for Ungauged Reservoir Management: A Case of Situ Cipondoh, Tangerang Indonesia
}

\author{
Juwarin Pancawati $^{{ }^{*}} \quad$ M Yanuar J Purwanto $^{2} \quad$ Widiatmaka $^{3} \quad$ Siti Nurisjah $^{4} \quad$ Bambang Pramudya $^{5}$ \\ 1.The Study Program of Natural Resources and Environmental Management, Bogor Agricultural University, \\ Bogor, 16143, Indonesia \\ 2.Department of Civil and Environmental Engineering, Bogor Agricultural University, Dramaga 16680, \\ Indonesia \\ 3.Departement of Soil Science and Land Resources Management, Bogor Agricultural University, Dramaga, \\ 16680, Indonesia \\ 4.Indonesian Landscape Architecture Association, Jakarta 10260, Indonesia \\ 5.Departement of Engineering and Biosystem, Bogor Agricultural University, Bogor, 16143, Indonesia
}

\begin{abstract}
Situ Cipondoh is an artificial urban lake, and it is one of the raw water sources for the Regional Drinking Water Company (PDAM) of Tangerang Munacipality. Even though relatively has a large capacity, the lake often overflows during the rainy season and recedes during the dry season. This study aims to optimize the lake's reservoirs and analyze the reliability. Tank model simulation was carried out to optimize the water level so that the reservoir can accommodate the flood discharge and provide raw water. Simulations are carried out in eight scenarios, to saw the impact of implementing operating rules, conservation of catchment areas and the increase in raw water intake to the reliability. Based on the modeling, rule curve of water levels should be ranging from $3.10-3.43 \mathrm{~m}$ in wet years, and $2.76-3.23 \mathrm{~m}$ in dry years. Meanwhile, based on the scenarios the lake showed various results of reliabilities (\%) depend on the implementation of operating rules and the level of the catchment area's conservation. To maintain the reliability of Situ Cipondoh, the increase of PDAM raw water treatment capacity from 30 liters/ second to 150 liters/ second, needs to be accompanied by several efforts to increase water absorption in the catchment area.
\end{abstract}

Keywords: reliability, reservoir, tank model, urban lake, water level

DOI: $10.7176 / \mathrm{JEES} / 9-1-07$

\section{Introduction}

Situ Cipondoh is a constructed wetland that was built during the Dutch East Indies era as a surface water supply and agricultural irrigation (Puspita et al. 2005). Along with the Tangerang City development, most agricultural irrigated land has been lost and turned into settlement. Recently Situ Cipondoh is one of raw water sources to meet clean water needs, as well as being recreation site for surrounding people (Pancawati et al. 2016).

The area of Situ Cipondoh is 126.71 ha with an average depth of $3 \mathrm{~m}$ (DLH 2008). Based on these data, it is estimated that the Situ Cipondoh reservoir has capacity at 3.8 million $\mathrm{m}^{3}$. The reservoir inlets are small rivers which are drainage channels as well as channels of gray water waste disposal. There are four main inlets on the south side, and on the north side there is one outlet equipped with a sluice gate, so that at any time it can be opened to reduce the reservoir load. Although the reservoir has considerable storage potential, almost every peak of the rainy season Situ Cipondoh overflowed. Conversely, in long dry season, like what happened in May to November 2015, the elevation of Situ Cipondoh water level down drawing to $17.5 \mathrm{~m}$ above sea level (asl) or remaining only about $10 \mathrm{~cm}$ from the dead storage level. The average of dept becomes less than $1 \mathrm{~m}$, and this disrupts the utilization activities of raw water intakes by the Regional Water Company (PDAM) and tourism. This condition indicates that Situ Cipondoh water storage management has not been done optimally. Until this research was carried out there was not enough information available regarding the model of water level behavior in the reservoir which is the basis for Situ Cipondoh water planning and management.

This study investigates the use of tank models to study the behavior of Situ Cipondoh water level based on daily rainfall data. The tank model is a method based on the hypothesis that runoff and infiltration flow is a function of the amount of water in the soil (Sugawara 1985). Models can be constructed in such a way as to represent the different conditions in the catchment area. The tank model, in addition to being able to explain initial loss from rainfall, can also show some components of runoff, interflow, base flow and percolation / infiltration flows as well as those stored as ground water content (Surya et al. 2014). As with the application to the catchment area, the application of the tank model to the reservoir is expected to help get an idea of the potential for water losses due to percolation and seepage on the reservoir that has been difficult to measure in Situ Cipondoh.

Therefore, this study aims to predict flow discharge from catchment area, optimize reservoir function through tank model simulation, and analyze the reliability in accommodating overflow flood discharge and provide raw water for PDAM. The results of this study are expected to provide information about the Situ 
Cipondoh reservoir system and become the basis for policy making in reservoir management, especially in managing the water level of Situ Cipondoh.

\section{The Study Area}

\subsection{General Information}

Situ Cipondoh is located in Tangerang which is the Jakarta buffer city (Figure 1). This area is a lowland (16-18 $\mathrm{m}$ asl) with a slope of less than 3\%. The catchment area of Situ Cipondoh covers an area of 4,160.6 ha, most of them were built-up areas (37.2\%) with an infiltration rate of $44.7 \%$ (Table 1 ).

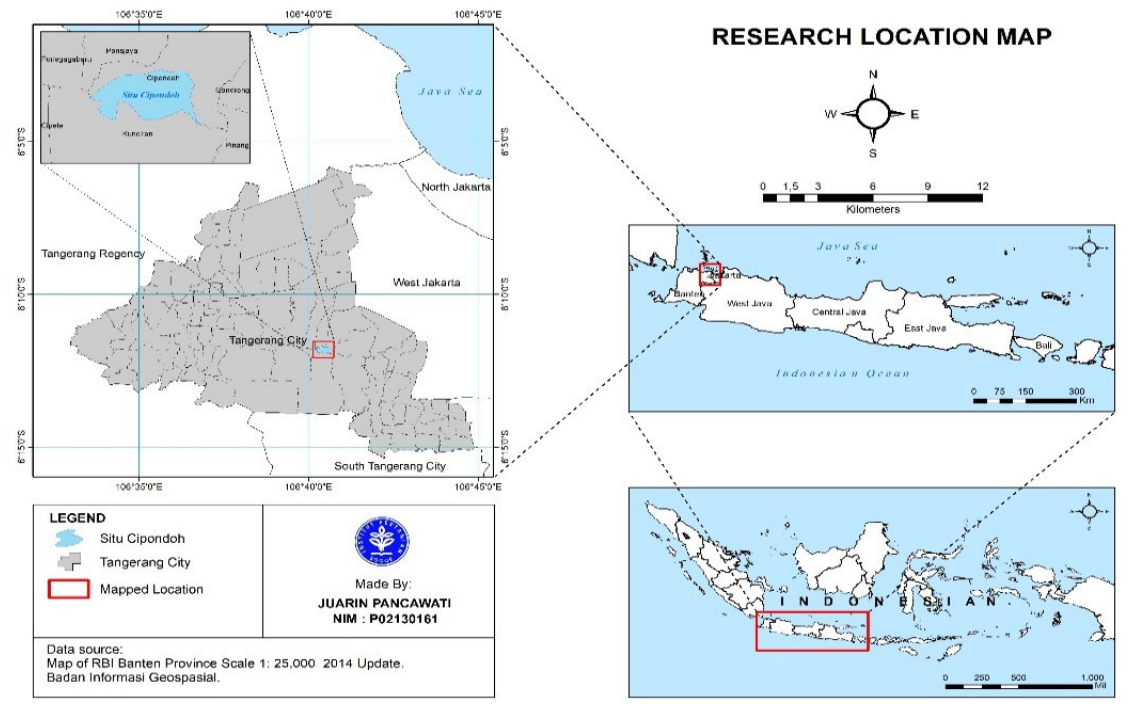

Figure1. Location of Study Area (Source: BIG 2018)

Table 1. Infiltration Rate of Situ Cipondoh Catchment Area

\begin{tabular}{|l|c|c|c|}
\hline Land Cover Type & Watershed area (\%) & $\begin{array}{c}\text { Water infiltration level for } \\
\text { this landuse (\%) }\end{array}$ & $\begin{array}{c}\text { Water infiltration level of } \\
\text { watershed (\%) }\end{array}$ \\
\hline Paddy Fields & 18.6 & 33.4 & 6.21 \\
\hline Mix garden & 19.3 & 57.7 & 11.14 \\
\hline Bushes and Grassland & 24.8 & 57.7 & 14.31 \\
\hline Residential & 37.2 & 35.0 & 13.02 \\
\hline Total Imperviousness & & 44.68 \\
\hline
\end{tabular}

\subsection{Observed Data}

There is no historical record of inflow debit data or records of Situ Cipondoh reservoir water level data. For the purpose of calibrating the tank model, observations of daily flow data from 4 inlets and 1 outlet, as well as the water level of Situ Cipondoh, were carried out for one year starting from April 12015 to March 272016.

\subsection{Presipitation}

Precipitation was used only as input data for the Tank Model. In this study, daily precipitation data was obtained from two climate stations, namely the Tangerang Weather Station and the Pondok Betung Weather Station. Areal precipitation was calculated using the Thiesen Polygon method. Calculation of areal precipitation using the equation (1).

$$
P=\sum \frac{P_{i} \cdot a_{i}}{A}
$$

With $P$ is the areal precipitation $(\mathrm{mm}), P_{i}$ is precipitation at station-i, $a_{i}$ is the area that affected by station-i, and $A$ is the total area of the catchment.

\section{Research Flow}

Modeling flow discharge of catchment area ideally uses historical debit data records. However, in the study area, no data was found, so the first step of this study was to predict the discharge of catchment area from precipitation data. In this study, Sugarawa Tank Model was used to transform the precipitation data into discharge flow data. 
The output of the catchment area tank model then used as input in the next step, which was water balance analysis.

The water balance analysis investigated by routing all elements of water traffic in Situ Cipondoh. The level of situ water will change with the entry and exit of some water from/into the reservoir. The basic equation for simulating the water balance is a function of the inflow, outflow, and water storage. The calculations are carried out using the basic equation as follows:

$$
\Delta W L=I-O
$$

With $\Delta W L$ is the change in water level $(\mathrm{m}), \mathrm{I}$ is the amount of water that flow into the reservoir $(\mathrm{m})$, and $\mathrm{O}$ is the amount of water flow out of the reservoir $(\mathrm{m})$. The unit of water that flow in/out from the reservoir was normalized by the area of Situ Cipondoh. The water that flow into the reservoir consists of inflow discharge from the catchment area and direct precipitation. While the water that flow out of the reservoir system consists of losses due to evaporation, seepage and infiltration, water intake of PDAM, and water release through spillways. In detail the equation (2) can be displayed as follows:

$$
\begin{aligned}
\overline{W L}_{t}-\overline{W L}_{t-1} & =\left(\bar{I}_{t}+\bar{P}_{t}\right)-\left(\bar{R}_{t}+\bar{E}_{t}+{\overline{P D A M_{t}}}+\bar{M}_{t}+\bar{L}_{t}\right) \\
\overline{\Delta W L}_{t} & =\left(\bar{I}_{t}+\bar{P}_{t}\right)-\left(\bar{R}_{t}+\bar{E}_{t}+\overline{P D A M_{t}}+\bar{M}_{t}+\bar{L}_{t}\right)
\end{aligned}
$$

With $\overline{W L}_{t}$ is average of water level on day $\mathrm{t}, \overline{W L}_{t-1}$ is average of water level on day (t-1), $\bar{I}_{t}$ is average of inflow on day $\mathrm{t}, \bar{P}_{t}$ is average of direct precipitation on day-t, $\bar{R}_{t}$ is average of water release on day $\mathrm{t}, \bar{E}_{t}$ is average of evapotranspiration on day $\mathrm{t}, \bar{M}_{t}$ is average of pond irrigation on day $\mathrm{t}, \overline{P D A M}_{t}$ is Average of raw water intake by PDAM on day $t, \bar{L}_{t}$ is average of other water losses on day $\mathrm{t}$.

In this study, the reservoir water level was simulated using a Reservoir Tank Model which was applied to 2 types of inflow, namely wet and dry years. From the simulation, the operating pattern curve for each inflow type was obtained. Two rule curves that obtained from simulations are used as guidance in controlling the water level so that not reach a critical point. At the end of the operation, the storage needs to set up to the optimum level before the next operation period. The goal of this simulation was to maintain water levels of the storage so that it is suitable for PDAM raw water supplies and tourism while preventing overtopping.

Simulation of the water storage was carried out to obtain the best operating rule plan. Figure 2 presents the stages of operating rules preparation.

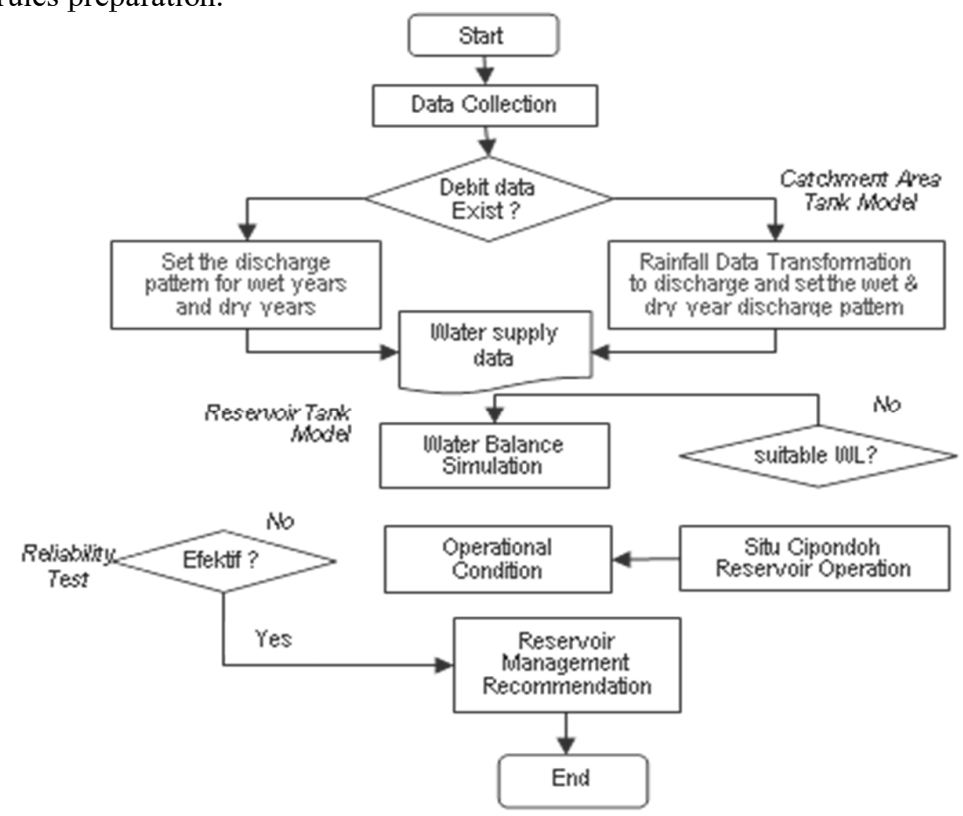

Figure 2. Stages in Preparing Recommendation for Water Leel Management of Situ Cipondoh

\section{Tank Model}

\subsection{Structure}

This study uses two sets of tank models, catchment area tank models (CTM) and reservoir tank models (RTM). The catchment tank model was used to predict inflow discharge, while the reservoir tank model was used to simulate reservoir water balance. 
The CTM structure consists of two parallel arranged tanks and one single tank. The structure was adopted from the urban area tank model compiled by Ou et al. (2017). The CTM structure represents two types of land surface, namely permeable surface and impermeable surface. The impermeable tank model consists of a single tank, while the permeable tank model consists of two tank layers. In the permeable tank model, the upper tank has two side outlets and one bottom outlet. The side outlet on the upper tank illustrates runoff, the bottom outlet of the tank represents the base flow, while the bottom outlet describes the percolation (Sugarawa 1985). Equation 3 was used to obtain the simulation value of catchment area discharge (Ou et al. 2017)

$$
\begin{array}{ll}
Q_{(i(t))} & =a_{i} \times\left[X_{(i(t))}-h_{i}\right] \\
Z_{(i(t))} & =z_{i} \times X_{(i(t))} \\
X_{(i(t))} & =X_{(i(t-1))}+\left(P_{t}-E T_{t}\right)-Q_{i(t)}-Z_{(i(t))} \\
Q_{L U i(t)} & =\sum Q_{(i(t))} \\
Q_{(C T M(t))} & =\sum\left[C_{L U} \times Q_{(L U(t))}\right]
\end{array}
$$

With $Q_{(i(t))}$ is the discharge from the outlet side of the tank-i on day t, $Z_{(i(t))}$ is percolated water from the tank $\mathrm{i}$ on day t, $X_{(i(t))}$ the water content of tank -i on day t, $Q_{L U i(t)}$ is the discharge on land use-i on day t. $Q_{C T M(t)}$ is the total catchment discharge on day $t$.

The tank model used in simulating the water level of the Situ Cipondoh reservoir consists of three tanks arranged vertically. The upper tank illustrates the amount of water stored in the reservoir, while the second and third tanks describe the condition of the base layer. Inputs on this tank model are direct precipitation, inflow discharge (output of catchment tank model), evaporation, evapotranspiration, water release, PDAM intakes, and pond irrigation. The reservoir water level is obtained from the sum of the water level (Xi) in the reservoir (upper tank) and bottom layer of the reservoir (bottom tank). One reason for the use of tank models in this water balance analysis is the presumption of large amounts of water losses that are not recorded. By using a tank model, the amount of water losses due to leakage of reservoirs and infiltration can be predicted. The structure of the tank model is generally presented in Figure 3 .

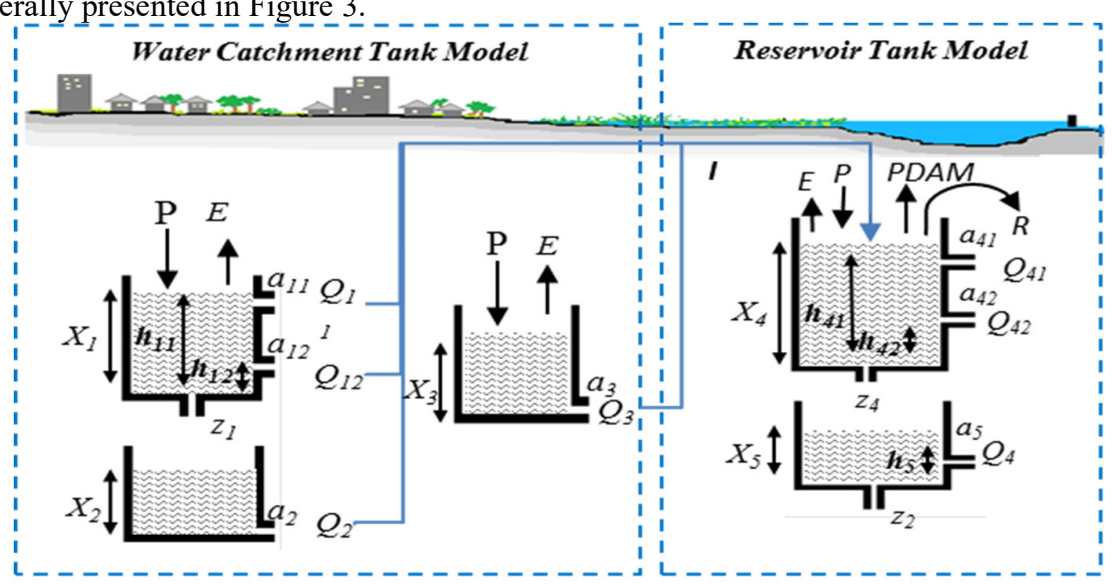

Figure 3. Schematic of a tank model

\subsection{Callibration}

To obtain the best performance of tank models, Calibration done by retried (tried-error) the value of tank's coefficient value namely; percolation coefficient (z), side outlet coefficient (a), the height of the side outlet (h), and the water content of tank (X), (Surya et al. 2014).

The statistical criteria used to evaluate the tank model performance were coefficient of determination $\left(\mathrm{R}^{2}\right)$ and Nash-Sutcliffe Efficiency (NSE). The coefficient of determination is the proportion of the total diversity of observed data that can be explained by the model. The values range from 0.0 to 1.0 . The closer it is to 1.0 , the better the performance of the model. A decent tank model is used if the $\mathrm{R}^{2}$ value produced was greater or equal to 0.5 (Sutoyo \& Purwanto 1999; Moriasi et al. 2015; Hidayat et al. 2016). The NSE value shows how well the plot of the value of the simulation results was compared to the observation value, according to line 1:1. NSE values range from $-\infty$ to 1.0. The closer it is to 1.0 , the better performance of the model. Criteria for evaluating the performance of tank models for daily scale are feasible if the NSE value was greater or equal to 0.5 (Moriasi et al. 2015; Tahir et al. 2013).

The calibration process of the catchment tank model was carried out to obtain the simulation discharge data which was close to the observation data. The best value of determination $\left(\mathrm{R}^{2}\right)$ that obtained from retrying process was 0.8073 . The effectiveness of the model to estimating the discharge is good (Moriasi et al. 2015), it's reflected on the Nash-Sutcliffe Efficiency (NSE) value of 0.7020. These results indicate that the calibration process was valid. Figure 4 presents the result of calibration using the tank model coefficients listed in Table 2. 
Table 2. Situ Cipondoh Catchment Tank Model Coefficient

\begin{tabular}{|l|c|c|}
\hline \multicolumn{1}{|c|}{ Parameter } & Symbol & Coefficient \\
\hline Tank 1 groundwater content & $\mathrm{X}_{1}$ & 70 \\
\hline Tank 2 groundwater content & $\mathrm{X}_{2}$ & 120 \\
\hline Tank 3 groundwater content & $\mathrm{X}_{3}$ & 0.028 \\
\hline Tank outlet coefficient 1-1 & $\mathrm{a}_{11}$ & 0.027 \\
\hline Tank outlet coefficient 1-2 & $\mathrm{a}_{12}$ & 0.021 \\
\hline Tank outlet coefficient 2 & $\mathrm{a}_{2}$ & 1.090 \\
\hline Tank outlet coefficient 3 & $\mathrm{a}_{3}$ & 100 \\
\hline Tank outlet height 1-1 & $\mathrm{h}_{11}$ & 150 \\
\hline Tank outlet height 1-2 & $\mathrm{h}_{12}$ & 0.195 \\
\hline Tank 1 percolation coefficient & $\mathrm{z}_{1}$ & . \\
\hline
\end{tabular}

The coefficient values in Table 2 show that on the land with permeable surface, the groundwater content in the lower layer tends to be higher than the top layer. The ability of the lower layer to drain water tends to be smaller than the layer above it. The ability of the bottom layer to drain water is smaller than the upper layer. The soil type of Situ Cipondoh catchment area is ultisol (Tangerang City DBMSDA, 2015). This soil type generally has low porosity that reflected in the small value of the percolation coefficient $(\mathrm{z})$
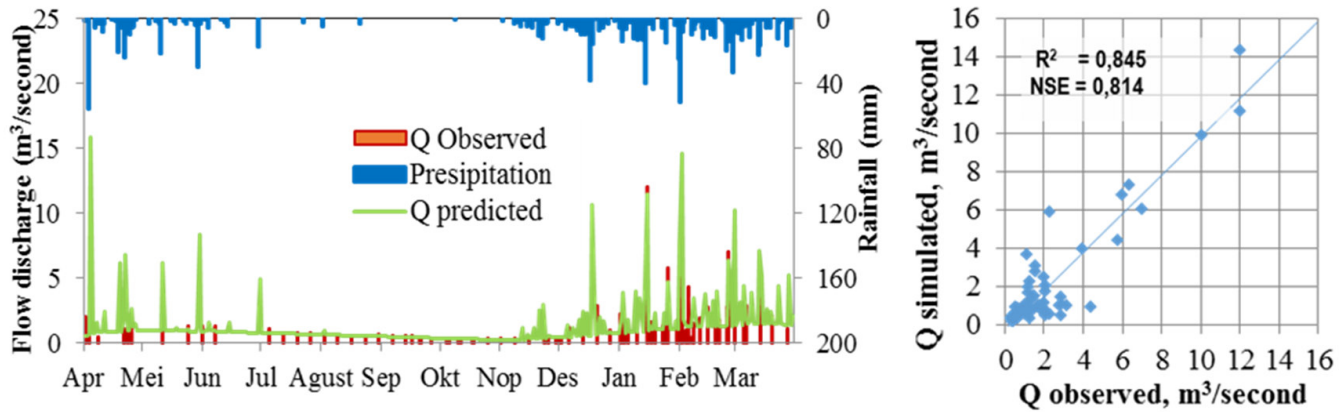

Figure 4. Results of Catchment Area Tank Model Callibration Using April 2015-March 2016 data

The calibration of Reservoir Tank Model was carried out with the same steps as the catchment tank model calibration, which is done by changing the coefficient values of the tank model (Table 3). Input of tank reservoir model is discharge flow of catchment area, rainfall, evaporation, output flow from sluice gates, water intake of PDAM and pond irrigation. Table 3 presents the coefficients of the calibration results using daily data from the period April 2015 to March 2016.

Table 3. Situ Cipondoh Reservoir Model Coefficient

\begin{tabular}{|c|c|c|}
\hline Parameter & Symbol & Coefficient Value \\
\hline Tank water level 1 & X4 & 1000 \\
\hline Tank water level 2 & X5 & 1200 \\
\hline Tank water level 3 & X6 & 1300 \\
\hline Tank outlet coefficient 1-1 & $\mathrm{a} 41$ & 0.380 \\
\hline Tank outlet coefficient 1-2 & $\mathrm{a} 42$ & 0.010 \\
\hline Tank outlet coefficient 2 & $\mathrm{a} 5$ & 0.001 \\
\hline Tank outlet coefficient 3 & $\mathrm{a} 6$ & 0.005 \\
\hline Tank outlet height 1-1 & $\mathrm{h} 41$ & 500 \\
\hline Tank outlet height 1-2 & $\mathrm{h} 42$ & 800 \\
\hline Tank outlet height 2 & $\mathrm{h} 5$ & 900 \\
\hline Tank outlet height 3 & $\mathrm{h} 6$ & 1600 \\
\hline Tank 1 percolation coefficient & $\mathrm{z} 4$ & 0.70 \\
\hline Tank 2 percolation coefficient & $\mathrm{z} 5$ & 0.050 \\
\hline Tank 3 percolation coefficient & $\mathrm{z} 6$ & 0.020 \\
\hline
\end{tabular}

Performance evaluation of tank models is carried out by comparing the water level of simulation results with water level observation. Figure 5 presents a graph of the water surface resulting from the calibration of the Reservoir Tank Model (RTM). The calibration with a combination of these coefficients obtains a value of determination $\left(\mathrm{R}^{2}\right)$ of 0.775 and Nash-Sutcliffe Efficiency (NSE) of 0.612. The value was good and satisfying (Moriasi et al. 2015), so it can be concluded that the calibration process has been going well. This calibration result was used to simulate changes in reservoir water level in three discharge type scenarios, namely wet years 
and dry years.
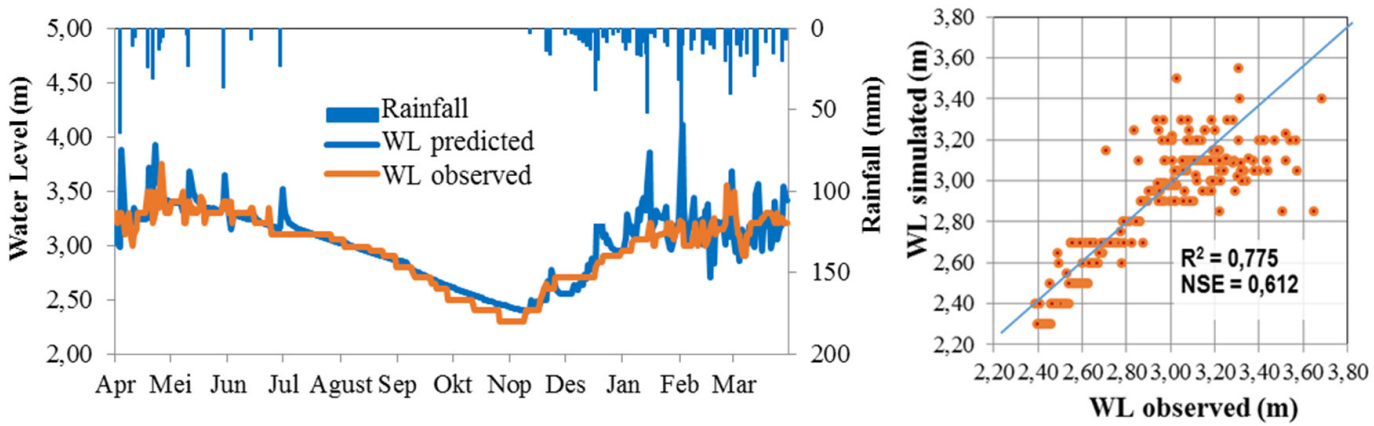

Figur 5. Results of Reservoir Tank Models Calibration Using April 2015-March 2016 data

\section{Discharge Flow of Catchment Area}

12-year daily discharge data is obtained by transforming rainfall data using a calibrated catchment tank model. The data then grouped into wet year discharge and dry year discharge data. The daily average of the two types of debits is presented in Figure 6

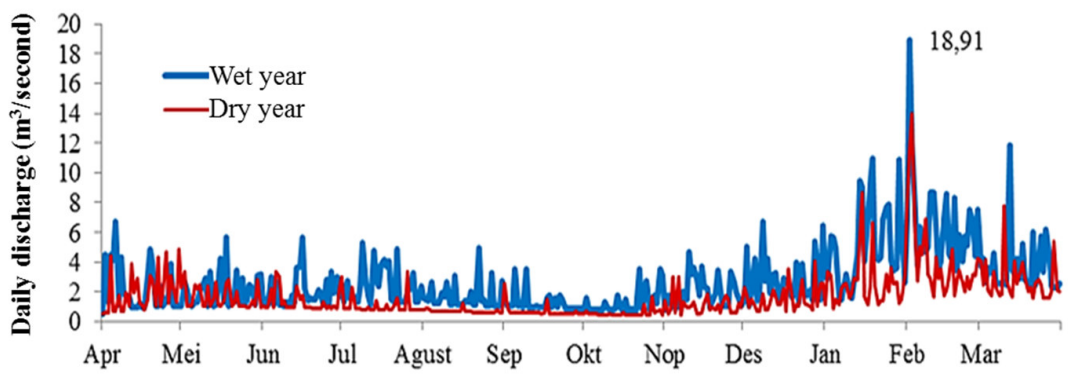

Figure 6. Average daily inflow debit in Wet and Dry Years based on 2004 to 2016 rainfall data

The average discharge of dry year was $1.65 \mathrm{~m}^{3} / \mathrm{second}$. In the dry year, the decrease of discharge began to occur in May and recede to the lowest level for three consecutive months from August to October with a flow between $0.54-0.68 \mathrm{~m}^{3} / \mathrm{second}$. The increase of discharge generally occurs in October and will peak in midJanuary to early February. The average discharge of wet years was $2.59 \mathrm{~m}^{3} / \mathrm{second}$. At the peak of the rainy season the highest monthly average discharge was $6.38 \mathrm{~m}^{3} / \mathrm{second}$. The highest daily debit could reach 18.91 $\mathrm{m}^{3} /$ second occurred after high intensity rain (more than $40 \mathrm{~mm} /$ day) for 3 consecutive days.

\section{Simulation of Reservoir Water Balance}

Water balance was used as a consideration material of the storage water usage in meeting the water needs of the community whose allocation is influenced by the amount of water released through the spillway, evaporation, evapotranspiration, percolation, seepage, water intake of PDAM, and pond irrigation.

Water level decrease occurs when an amount of water that entering into reservoir less than the coming out ones, and vice versa. Figure 7 shows a graph of the relationship between water availability and water loss from the reservoir system from the period April 2015 to March 2016.

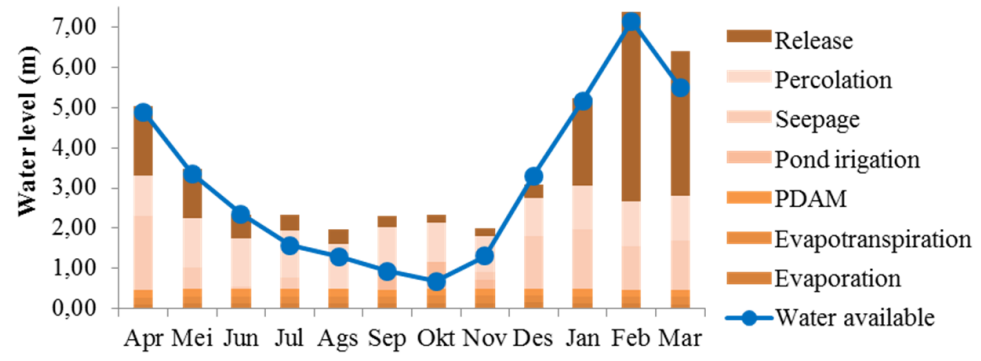

Figure 7. Graph of Water Balance In The Situ Cipondoh Reservoir For The Period April 2015- March 2016

From July to November water losses was higher than water availability. During that month's water losses were mainly caused by high percolation (42.4-57.2\%) and pond irrigation intake (10.8-23.3\%). Highest water shortage occurred in October at $1.65 \mathrm{~m}$ which means that water withdrawal pattern that occurred in October 
results in a water storage deficit of $1606999.0 \mathrm{~m}^{3}$.

\subsection{Preparation of water release patterns}

Simulation of the pattern of storage operations was carried out to obtain the best operating pattern. Simulation of reservoir operations carried out was a simulation of single reservoir operation, so the inputs and outputs that used in the simulation were used for one reservoir only. Water level management of Situ Cipondoh was prepared with the following rule:

- The highest limit of water level is $3.50 \mathrm{~m}$. This limit is the highest tolerance limit based on observation and information retrieval. Water levels that exceed this threshold cause overflow flooding that inundates settlements and harms fisheries.

- The lowest limit of water level is $2,90 \mathrm{~m}$. Water level that below this threshold will obstruct tourism and water intake of PDAM activities.

- At the end of the operation, the water level was sought higher than to the initial beginning of the operation

- The outlet capacity was $35 \mathrm{~m}^{3} / \mathrm{second}$, and the need of flushing drains (minimum discharge) were 0.14 $\mathrm{m}^{3} /$ second

- the order of water needs fulfillment priority are; 1) raw water for PDAM, 2) the needs for flushing drains, 3) water level for tourism, 4) pond irrigation

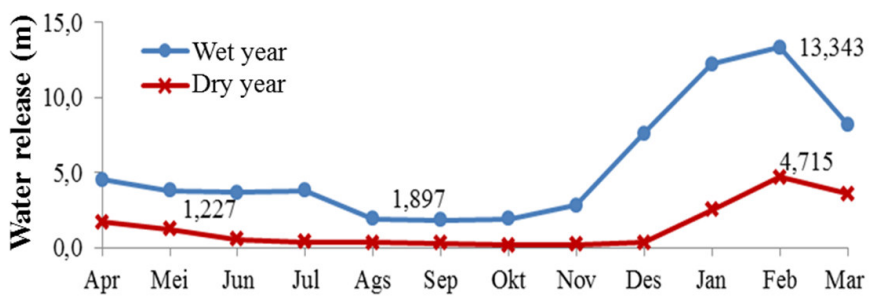

Figure 8. The reservoir operation pattern of the resulting from the TMA simulation using the storage tank model

Based on this, the water release operation plan was prepared for two types of conditions, wet and dry years, as presented in Figure 8. The plan release is obtained by accommodating water level simulations using a reservoir tank model, with the water level at the end of the reservoir operation greater than at the end of water level operation.

\subsection{Rule Curve Situ Cipondoh Reservoir}

The water release plan was obtained by simulating water level in the reservoir tank model, by attempting the water level in the safe range about $2.70 \mathrm{~m}$ to $3.70 \mathrm{~m}$, and at the end of the operating period, the water level must be higher near the initial level.

The release pattern from the optimization obtained water level which becomes the rule curve for the operation of the Situ Cipondoh reservoir in the wet year and dry year (Figure 9). The rule curve that obtained from the simulation results shows that the low tide period for dry years starts from May to October, and for wet years begins August to October.

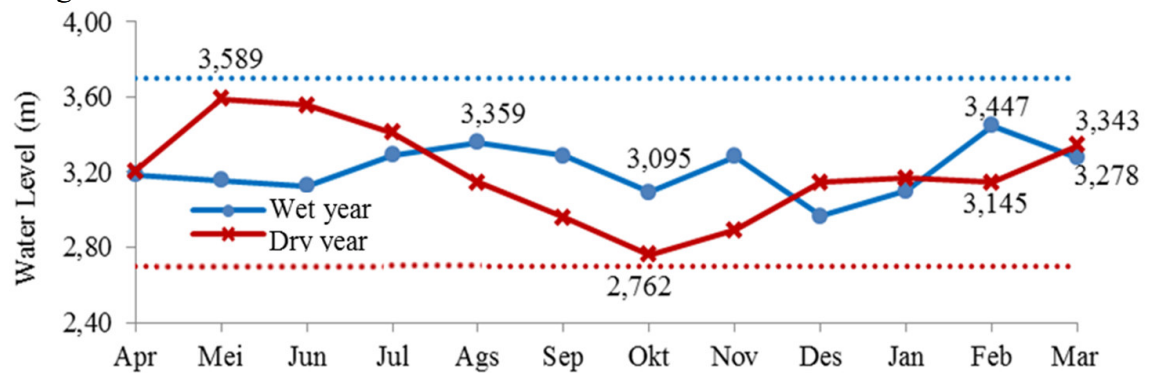

Figur 9. Rule curve simulation results of the storage tank model

The period of reservoir water level increase occurs at October both in wet years and dry years. During this period, the increase of water level for wet years will be faster than dry years. Based on the result of water level optimization, the operating rules for Situ Cipondoh reservoir are as follows

- During decrease periods (emptying), to anticipate water deficit:

- In dry years, water release was set at minimum starting in May, so that the decrease in water level will not be less than $2.76 \mathrm{~m}$

- In wet years, the release is set to a minimum level starting in August, so the lowest water level was expected not to be less than $3.10 \mathrm{~m}$. 
- During increase period (charging), to anticipate overtopping:

- In the wet year, the maximum release of reservoir water to anticipate flooding began in December. Water level needs to set $0.20 \mathrm{~m}$ lower than the normal level $(3.00 \mathrm{~m})$ so that the highest increase in water level does not exceed $3.45 \mathrm{~m}$..

- In dry years, water release to anticipate an overflow has to start in January. The water level is set at a low level so that the increase in water level at the peak of the rainy season does not exceed $3.15 \mathrm{~m}$

\section{Reliability of Cipondoh Situ As A Reservoir of Flood Discharge and Raw Water Providers}

The Tangerang City Health Office stated that $79.88 \%$ of the population of Tangerang City had used clean water services, but only $21.92 \%$ were served by the PDAM. Increasing PDAM water treatment capacity needs to carry out by adjusting the availability of raw water in existing surface water sources. The evaluation was carried out to assess the reliability of the reservoir when the PDAM's processing capacity was increased from 30 litres/ second to 150 litres/ second.

Beside of the water uses, the discharge of the catchment area influences the fluctuation of the water level of Situ Cipondoh either. Urban lake generally have a ratio of inundation area to less than 10: 1, this meaning that catchment area exert a strong influence on the water body conditions (Schuerler \& Simpson 2001). Land use change in urban catchments can result in significant changes to the rain-runoff relationship. In Bussiness as Usual (BaU) conditions, the infiltration rate of the Situ Cipondoh catchment area was 44.7\% (Arsyad 2006; Setyowati 2010). A set of scenarios were prepared to simulate water level behaviour by increasing the catchment area permeability to $60.0 \%$ and $75.0 \%$. The flow discharge of catchment area will become more stable by increasing water infiltration (Surya et al. 2014, Ou et al. 2017). Based on that description, the result of Situ Cipondoh operation at various recharge levels and different raw water intake of PDAM is shown in Figure 10.
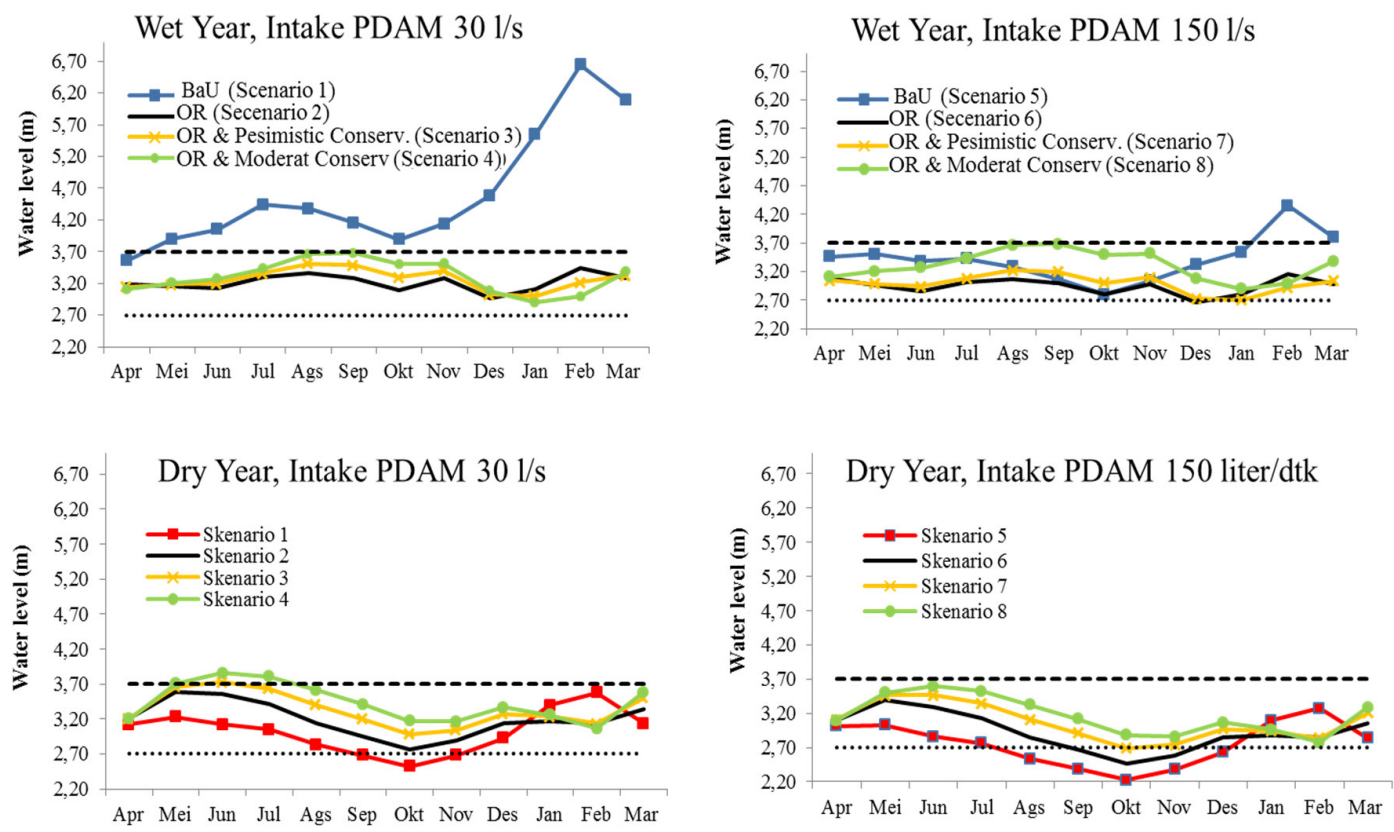

Figure 10. Results of Simulating Situ Cipondoh Reservoir in Various Operating Conditions

Even though it has implemented operating rules, the increase of PDAM's processing capacity from 30 liters/second to 150 liters/second in the dry year can result decreasing of reliability from $97.3 \%$ (scenario 2) to $72.9 \%$ (scenario 5). Increasing raw water intake will result in lower water levels at the peak of the dry season, which are from $0.009 \mathrm{~m}$ to $0.132 \mathrm{~m}$ from the allowable minimum water level $(2,700 \mathrm{~m})$. If the PDAM's process capacity would be increased, conservation of catchment areas could be an alternative to maintain the performance of the Situ Cipondoh reservoir. The increase in catchment infiltration rate from $44.7 \%$ to $75.0 \%$, at the same level of raw water intake, could increase the reliability of Cipondoh in the dry year from $72.9 \%$ (scenario 6) to $98.6 \%$ (scenario 8). The resulting test of reliability in various operating conditions completely present in Table 4. 
Table 4 Situ Cipondoh Reliability In Various Operating Conditions Scenarios

\begin{tabular}{|c|c|c|c|c|c|c|}
\hline \multirow{3}{*}{ Scenario } & \multicolumn{3}{|c|}{ Wet year } & \multicolumn{3}{|c|}{ Dry year } \\
\hline & \multirow{2}{*}{$\begin{array}{c}\text { Reiability } \\
(\%)\end{array}$} & \multicolumn{2}{|c|}{ Vulnerability (m) } & \multirow{2}{*}{$\begin{array}{c}\text { Reliability } \\
(\%)\end{array}$} & \multicolumn{2}{|c|}{ Vulnerability (m) } \\
\hline & & Overflow Aver & Low Tide & & Overflow Average & Low Tide \\
\hline 1 & 7,7 & 0,991 & 0,000 & 76,7 & \begin{tabular}{|c|}
0,299 \\
\end{tabular} & 0,102 \\
\hline 2 & 98,1 & 0,411 & 0,028 & 97,3 & 0,120 & 0,009 \\
\hline 3 & 98,9 & 0,112 & 0,043 & 90,4 & 0,051 & 0,000 \\
\hline 4 & 94,5 & 0,390 & 0,075 & 76,7 & 0,113 & 0,000 \\
\hline 5 & 81,9 & 0,397 & 0,037 & 54,5 & 0,169 & 0,269 \\
\hline 6 & 87,9 & 0,215 & 0,112 & 72,9 & 0,079 & 0,132 \\
\hline 7 & 90,1 & 0,005 & 0,000 & 91,8 & 0,002 & 0,000 \\
\hline 8 & 94,5 & 0,041 & 0,077 & 98,6 & 0,000 & 0,000 \\
\hline
\end{tabular}

The overflow flooding vulnerability area is relatively decreased by implementing the operation and conservation rule of the catchment area. Without the operation rules, the average of water level increasing can reach $0.99 \mathrm{~m}$ more than the maximum allowable limit $(3.70 \mathrm{~m})$. But with the implementation of operation and conservation rules, runoff dropped to $0.04 \mathrm{~m}$. In general, the reliability of Situ Cipondoh is relatively increased with the implementation of the operation and conservation rules of the catchment area. This is reflected in the better value of Situ Cipondoh's reliability along with the increase in absorption rate in the catchment area. Increasing the water absorption capacity in the catchment area can be done through making infiltration wells, reservoirs and multiplying biopores (Ou et al. 2017; Budinetro et al. 2012; Wilson et al. 2014).

\section{Conclusion}

Tank model simulations can be used to optimize the reservoir function. Optimization results in wet year conditions obtained a minimum Water Level (TMA) of $3.10 \mathrm{~m}$ at low tide, and a maximum TMA of $3.43 \mathrm{~m}$ in the upward period. The dry year condition obtained at the lowest TMA is $2.76 \mathrm{~m}$, and the maximum water level increase is $3.23 \mathrm{~m}$ in the rising period.

The implementation of optimization rules can increase the reliability of Situ Cipondoh from 7.7\% to $98.1 \%$. Conservation of catchment areas by increasing water infiltration can reduce overflow flood vulnerability and improve situ reliability in the raw water supply for PDAMs. To maintain the reliability of Situ Cipondoh, the increase in PDAM raw water treatment capacity from 30 litres/ second to 150 litres/ second, needs to be accompanied by several efforts to increase water absorption in the catchment area

\section{References}

[DLH] Dinas Lingkungan Hidup Kota Tangerang. (2008), "Water Resources Conservation and Damage Control of Tangerang City Water Resources". Tangerang City Environmental Agency, Tangerang.

[KLH] Kementerian Lingkungan Hidup. (2007), "Small Lakes Conservation Strategy in Jabodetabek Region". Ministry of Environment, Jakarta.

Arsyad, S. (2006), “Soil and Water Conservation”. IPB Press, Bogor

[BIG] Badan Informasi Geospasial. (2018), "Ina-Geoportal Peta Per Wilayah". http://tanahair.indonesia.go.id/portal-web/download/perwilayah\#

Budinetro, H.S., Fatchan, A.K., Sahid, M.N. (2012), "Control of Surface Flow Due To Changes in Land Use With The Concept of Low Impact Development. Proceeding of the National Civil Engineering Seminary UMS 2012: Building Sustainable Civil Engineering; Mei 26 th 2012; Surakarta, Indonesia, 100-111.

Hidayat L, Sudira P, Sahid S, Rachmad J. (2016), "Validation of the SWAT hydrological model on the catchment area of Mrica Reservoir". Agritech 36(4): 467-74.

Moriasi DN, Gitau MW, Pai N, Daggupati P. 2015. Hydrologic and water quality models: performance measures and evaluation criteria. Transactions of The ASABE 58(6):1763-1785.

Ou X, Bahram G, McBean E, Doherty C. (2017), "Investigation of The Tank Model For Urban Storm Water Management". Journal of Water Management Modeling 25: C421.

Pancawati J., Saifullah, Indaryanto F.R. (2016), "Valuation of Fishing Recreation in Situ Using Travel Cost Approach". Jurnal Perikanan dan Kelautan 6(1):51-60.

Puspita L., Ratnawati E., Suryadiputra I.N.N., and Meutia, A.A. 2005. "Artificial Wetland in Indonesia". Wetlands International - Indonesia Programme, Bogor.

Schuerler T, Simpson J. (2001), "Why urban lakes are different". Watershed Protection Technique 3(4):747750.

Setyowati D.L. (2010), "Relationship Between Rain and Runoff in Small Sub-watersheds of Forest Land, Rice Fields, Mixed Gardens in the Kreo River Basin”. Forum Geografi 24(1):39-56.

Sugawara, M. (1985), "Tank Model for The Derivation of River Discharge from Rainfall". Journal of 
Geography (Chigaku Zasshi) 94(4): 209-221.

Surya, R.A., M Yanuar J Purwanto, and Asep Sapei. (2014), “Tank Model to See The Effect of Land Use Changes on Runoff, Infiltration And Groundwater in Sub Watershed of Konaweha South East Sulawesi Indonesia. Journal of Environment and Earth Science 4(14), 107-117.

Sutoyo, Purwanto MYJ. (1999), "Estimation of Rain Based River Discharge Using a Tank Model in Cidanau Watershed, Serang". Keteknikan Pertanian 13(3), 25-39.

Tahir W, Aimme H, Hamid C. (2013), "Flood Forecasting Using Tank Model and Weather Surveillance Radar (WSR) Input for Sg Gombak”. International Journal of Civil \& Environmental Engineering 13(02), 42-46.

Wilson C.E., Hunt W.F., Winston R.J., Smith P. (2014), "Comparison of Runoff Quality and Quantity from A Commercial Low-Impact And Conventional Development In Raleigh, North Carolina. Journal of Environmental Engineering 141(2), 05014005.

Wurb AR. (1996),"Modelling and Analysis of Reservoir System Operations". Upper Saddle River, NJ (US): Prentice Hall PTR 